\title{
ANALISA KADAR AIR DAN UJI ORGANOLEPTIK IKAN SELAR (Selaroides leptolepis) DAN IKAN CAKALANG (Katsuwonus pelamis L)
}

\author{
Yakobus Kostan Imbir, Hens Onibala, Albert R. Reo
}

Fakultas Perikanan dan Ilmu Kelautan, Universitas Sam Ratulangi, Manado, Sulawesi Utara.

\begin{abstract}
ABSTRAK
Ikan Selar (Selaroides leptolepis) dan ikan Cakalang (Katsuwonus pelamis L) termasuk jenis ikan yang bernilai ekonomis tinggi dan biasanya dipasarkan dalam bentuk segar. Penelitian ini bertujuan untuk menganalisa kadar air dan uji organoleptik ikan Selar dan ikan Cakalang segar yang dipasarkan di pasar Tradisional Bahu, Manado. Hasil penelitian menunjukkan bahwa Nilai Rata-rata kadar air ikan Selar pada hari pertama jam 06:00 72,5\% dan pada jam 11:00 meningkat menjadi $73,1 \%$ sehingga pada jam 18:00 Wita terjadi penurunan kadar air 71,4\%. Dan nilai Rata-rata kadar air ikan Cakalang pada hari kedua pada jam 06:00, 72,6\% dan pada jam 11:00 Wita terjadi peningkatan 73,1\% sedangkan pada jam 18:00 terjadi penurunan kadar air 71,6\%. Hasil uji organoleptik ikan Selar dan ikan Cakalang pada kriteria mata, insang, daging dan perut, bau, tekstur. Menunjukkan bahwa pada jam 06:00 WITA kedua jenis ikan pelagis masih dalam keadaan segar, dan pada jam 11:00 WITA terjadinya perubahan suhu dan cahaya pasar yang kurang baik. Sehingga pada jam 18:00 WITA terjadinya penurunan tingkat kesegaran ikan yang sangat signifikan. Berdasarkan hasil analisa kadar air dan uji organoleptik ikan Selar dan ikan Cakalang menunjukkan dalam keadaan yang masih baik (segar).
\end{abstract}

Kata kunci: Selar, Cakalang, kadar air, organoleptik. Manado.

\section{PENDAHULUAN}

Dalam pembangunan ekonomi Indonesia, perikanan adalah kegiatan pemanfaatan sumber daya alam yang diarahkan dengan sasaran utama pencukupan kebutuhan pangan, peningkatan kesempatan kerja, peningkatan pendapatan devisa dan pemeliharaan lingkungan yang lestari (Winarno, F. G. 1980).

Perikanan adalah suatu kegiatan ekonomi yaitu usaha manusia memanfaatkan sumber daya alam dengan cara menerapkan kaidah teknologi secara ekonomis untuk mencapai kesejahteraan manusia melalui produksi hasil perikanan. Menurut llyas (1983) bahwa kegiatan terbesar dari hasil perikanan disalurkan dalam bentuk pemasaran segar terutama sebagai ikan basah baik yang didinginkan atau tanpa pendinginan.

Ikan merupakan komoditi yang mudah membusuk sehingga sangat sulit untuk mempertahankan kesegaran ikan sampai ke tangan konsumen (Afrianto dan Liviawaty 1989).

Prinsip penanganan ikan segar adalah mempertahankan kesegaran ikan dengan cara memperlakukan ikan dengan hati-hati, segera menurunkan suhu atau mendinginkan ikan sehingga mencapai suhu $0^{\circ} \mathrm{C}$ serta selalu memperhatikan waktu dan kecepatan bekerja selama rantai penanganan (1lyas, 1983).

Untuk itu perlu dilakukan penelitian untuk mempelajari cara penanganan hasil perikanan yang cepat dengan metode yang tepat agar tingkat kesegaran ikan dapat terus dipertahankan sampai ke tangan konsumen.

Berdasarkan Penelitian ini diharapkan dapat memberikan informasi mengenai tingkat kesegaran ikan yang ada di pasar Bahu. Penelitian ini bertujuan untuk mengetahui dua jenis ikan pelagis yang ditinjau dari tingkat kesegarannya, yang dianalisa dengan uji organoleptik dan kadar air ikan tersebut.

Penelitian ini dilaksanakan di Laboratorium Penanganan dan Pengolahan hasil Perikanan Fakultas Perikanan dan Ilmu Kelautan Universitas Sam Ratulangi dengan waktu pelaksanaan pada bulan OktoberNovember 2014.

\section{METODOLOGI PENELITIAN}

Metode yang digunakan dalam penelitian ini merupakan metode eksperimental dimana suatu penelitian yang dilakukan dengan cara mengubah suatu keadaan untuk melihat kejadian yang timbul akibat perubahan itu. (Mantjoro dkk., 1981). 


\section{Bahan Baku dan Alat}

Jenis ikan yang digunakan dalam penelitian ini adalah 2 yaitu Selar kuning (Selaroides leptolepis), Cakalang (Katsuwonus pelamis L). Alat yang di gunakan untuk analisa kadar air yaitu: Cawan porselen, desikator, wadah, pisau, pinset, timbangan analitik, thermometer, alat pengering berupa Oven. Sedangkan alat untuk pengujian organoleptik antara lain piring, lembaran penilaian, alat tulis, dan tissue.

\section{Tata Laksana Penelitian}

Tata laksana kerja penelitian ini dilakukan sebagai berikut:

1. Pengambilan sampel ikan segar hari pertama yaitu Pukul 06:00, 11:00 dan 18:00 WITA, berjumlah dua ekor ikan selar segar di pasar bahu. Ikan tersebut dibawa ke Laboratorium Penanganan dan Pengolahan Hasil Perikanan untuk dianalisa kadar air dan uji organoleptik.

2. Pengambilan sampel ikan segar hari kedua dengan jam yang sama ikan cakalang segar. berjumlah dua ekor ikan dibawa ke Laboratorium Penanganan dan Pengolahan Hasil Perikanan untuk dianalisa kadar air dan uji organoleptik.

3. Hari ketiga dengan jam yang sama ikan selar segar. berjumlah dua ekor ikan dibawa ke Laboratorium Penanganan dan Pengolahan Hasil Perikanan untuk analisa kadar air dan uji organoleptik.

4. Hari keempat dengan jam yang sama, ikan Cakalang segar berjumlah dua ekor ikan dibawa ke Laboratorium Penanganan dan Pengolahan Hasil Perikanan untuk analisa kadar air dan uji organoleptik.

\section{Analisa Statistik}

Hasil pengamatan laboratorium yang diperoleh dalam dua kategori yaitu hasil pengamatan bersifat eksploratif dan nilai pengamatan kuantitatif dilakukan perhitungan dengan nilai rata-rata, kemudian hasil perhitungan akan disajikan dalam bentuk tabel, sedangkan hasil pengamatan yang bersifat kualitatif disajikan dalam bentuk gambar grafik.

Analisa Kadar Air ( Sudarmadji, dkk., 1997 )

1. Cawan porselin dan tutupnya dicuci bersih dan kemudian dikeringkan dalam oven pada suhu $100-105^{\circ} \mathrm{C}$ selama satu jam.
2. Dengan tang penjepit, cawan porselen dikeluarkan dari oven dan dimasukan dalam desikator selama 30 menit, cawan porselen yang telah dingin kemudian ditimbang (A).

3. Sampai ditimbang dengan cawan porselen tersebut sebanyak \pm 2 gr (B).

4. Cawan porselen yang berisi sampel kemudian dimasukan kembali dalam oven pada suhu $100-105^{\circ} \mathrm{C}$ selama 24 jam.

5. Kemudian cawan porselen tersebut dikeluarkan lalu dimasukan ke dalam desikator selama 30 menit, lalu ditimbang (C).

6. Perhitungan: Kadar air $=\frac{B-C}{B-A} \times 100 \%$

\section{Uji Organoleptik ( SNI 1991)}

Pengujian organoleptik yaitu pengujian terhadap kondisi fisik ikan segar pada beberapa jenis ikan yang ada di pasar bahu dengan menggunakan penilaian score sheet ikan segar (SNI 01-2346-1991), untuk mengetahui tingkat kesegaran ikan dengan menggunakan indera sensori. Pengujian organoleptik dilakukan dengan menggunakan alat berupa score sheet organoleptik ikan segar. Pada score sheet menggunakan angka 1 sebagai nilai terendah dan angka 9 untuk nilai tertinggi. Pengujian organoleptik dilakukan oleh 15 orang panelis.

\section{HASIL DAN PEMBAHASAN}

\section{Analisa Kadar Air Ikan Selar}

Analisa kadar air pada sampel ikan Selar pada hari pertama dan hari kedua dapat di lihat pada Tabel 1 dan 2 di bawah ini.

Tabel 1. Hasil analisa kadar air ikan Selar (Selaroides leptolepis) hari pertama.

\begin{tabular}{|c|c|c|c|c|}
\hline $\begin{array}{l}\text { Jenis } \\
\text { ikan }\end{array}$ & $\begin{array}{c}\text { Waktu Pengambilan } \\
\text { Sampel }\end{array}$ & \multicolumn{2}{|c|}{$\begin{array}{l}\Sigma \text { Kadar } \\
\text { Air }(\%)\end{array}$} & $\overline{\mathbf{X}}$ \\
\hline Selar & Pagi (06:00 Wita) & $\begin{array}{l}74,05 \\
71,72\end{array}$ & $\begin{array}{l}72,73 \\
71,67\end{array}$ & 72,54 \\
\hline Selar & Siang (11:00 Wita) & $\begin{array}{r}74,52 \\
74,01 \\
\end{array}$ & $\begin{array}{l}72,24 \\
71,77 \\
\end{array}$ & 73,13 \\
\hline Selar & Sore (18:00 Wit & $\begin{array}{l}67,88 \\
72,67\end{array}$ & $\begin{array}{r}73,71 \\
71,60 \\
\end{array}$ & 71,46 \\
\hline
\end{tabular}

Tabel 2. Hasil analisa kadar air ikan Selar (Selaroides leptolepis) hari kedua.

\begin{tabular}{|c|c|c|c|c|}
\hline $\begin{array}{l}\text { Jenis } \\
\text { ikan }\end{array}$ & $\begin{array}{c}\text { Waktu Pengambilan } \\
\text { Sampel }\end{array}$ & \multicolumn{2}{|c|}{$\begin{array}{c}\Sigma \text { Kadar } \\
\text { Air (\%) }\end{array}$} & $\overline{\mathbf{X}}$ \\
\hline Selar & Pagi (06:00 Wita) & $\begin{array}{l}67,88 \\
72,67\end{array}$ & $\begin{array}{l}73,71 \\
72,60\end{array}$ & 71,71 \\
\hline Selar & Siang (11:00 Wita) & $\begin{array}{l}73,88 \\
75,42 \\
\end{array}$ & $\begin{array}{l}72,61 \\
76,00\end{array}$ & 74,48 \\
\hline Selar & Sore (18:00 Wita) & $\begin{array}{l}69,92 \\
70,73\end{array}$ & $\begin{array}{l}70,99 \\
69,85\end{array}$ & 70,37 \\
\hline
\end{tabular}


Pada Tabel 1 dan 2 menunjukkan bahwa nilai rata-rata kadar air ikan selar pada hari pertama dan hari kedua pada waktu pengambilan masih memenuhi SNI di atas 70 $80 \%$. Gambar grafik nilai rata-rata persentase kadar air ikan Selar pada hari pertama dan hari kedua dapat dilihat pada Gambar 1.

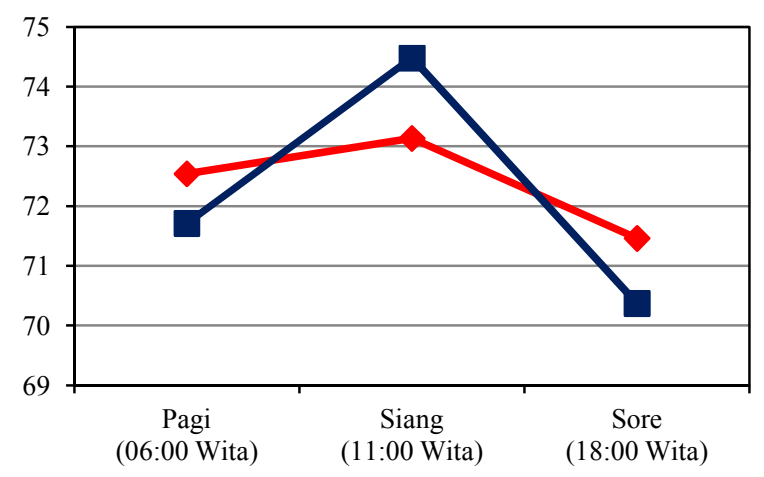

Gambar 1. Grafik kadar air pada ikan Selar (Selaroides leptolepis).

Bedasarkan hasil Penelitian yang ditunjukkan pada grafik kadar air di atas untuk sampel ikan Selar pada hari pertama dan hari kedua pada pukul 06:00 pagi 71,7-72,5\%. Dan pada pukul 11:00 terjadi kenaikan kadar air kurang dari 1,6\%. Sehingga pada jam 18:00 WITA kadar ikan selar terjadi penurunan. Namun dari perubahan kadar air tersebut baik hari pertama dan kedua, masih memenuhi SNI yaitu $70-80 \%$.

\section{Analisa Kadar Air Ikan Cakalang}

Hasil Analisa kadar air sampel ikan Cakalang pada pengambilan pertama dan kedua dapat dilihat pada Tabel 3 dan 4 di bawah ini.

Pada Tabel 3 dan 7, menunjukkan bahwa, nilai rata-rata kadar air ikan Cakalang pada pengambilan sampel pertama dan kedua pada waktu pengambilan masih memenuhi SNI di atas $70-80 \%$. Gambar grafik nilai rata-rata persentase kadar air ikan Cakalang pada pengambilan sampel pertama dan kedua dapat dilihat pada Gambar 2.

Berdasarkan hasil penelitian yang ditunjukkan pada Gambar 2 untuk sampel ikan Cakalang pada hari pertama dan hari kedua kadar air 06:00 WITA 72,6-73,2\%. Sehingga pada pukul 11:00 WITA terjadi penurunan kadar air kurang dari $0,2 \%$. Sehingga pada pukul 18:00 kadar ikan Cakalang terjadi penurunan. Namun dari perubahan kadar air ikan Cakalang baik pengambilan pertama dan kedua, Masih Memenuhi Standar SNI yaitu 70$80 \%$.

Tabel 3. Hasil analisa kadar air ikan Cakalang (Katsuwonus pelamis L) pengambilan sampel pertama.

\begin{tabular}{|c|c|c|c|c|}
\hline $\begin{array}{l}\text { Jenis } \\
\text { ikan }\end{array}$ & $\begin{array}{c}\text { Waktu Pengambilan } \\
\text { Sampel }\end{array}$ & \multicolumn{2}{|c|}{$\begin{array}{l}\Sigma \text { Kadar } \\
\text { Air }(\%)\end{array}$} & $\overline{\mathbf{X}}$ \\
\hline Cakalang & Pagi (06:00 Wita) & $\begin{array}{l}72,60 \\
73,85\end{array}$ & $\begin{array}{l}72,69 \\
73,67\end{array}$ & 73,20 \\
\hline Cakalang & Siang (11:00 Wita) & $\begin{array}{l}73,73 \\
72,25\end{array}$ & $\begin{array}{l}73,76 \\
72,12\end{array}$ & 72,96 \\
\hline Cakalang & Sore (18:00 Wita) & $\begin{array}{l}69,73 \\
69,95 \\
\end{array}$ & $\begin{array}{l}69,17 \\
68,37 \\
\end{array}$ & 69,31 \\
\hline
\end{tabular}

Tabel 4. Hasil analisa kadar air ikan Cakalang (Katsuwonus pelamis L) pengambilan sampel kedua.

\begin{tabular}{ccccc}
\hline $\begin{array}{c}\text { Jenis } \\
\text { ikan }\end{array}$ & \multirow{2}{*}{$\begin{array}{c}\text { Waktu Pengambilan } \\
\text { Sampel }\end{array}$} & \multicolumn{2}{c}{$\begin{array}{c}\boldsymbol{\Sigma} \text { Kadar } \\
\text { Air (\%) }\end{array}$} & \multirow{2}{*}{$\mathbf{X}$} \\
\hline \multirow{2}{*}{ Cakalang } & \multirow{2}{*}{ Pagi (06:00 Wita) } & 72,60 & 72,69 & \multirow{2}{*}{73,20} \\
\hline \multirow{2}{*}{ Cakalang } & \multirow{2}{*}{ Siang (11:00 Wita) } & 73,85 & 73,67 & 73,76 \\
\hline \multirow{2}{*}{ Cakalang } & \multirow{2}{*}{ Sore (18:00 Wita) } & 62,25 & 72,12 & 72,96 \\
& & 69,95 & 69,17 & \multirow{2}{*}{69,31} \\
\hline
\end{tabular}

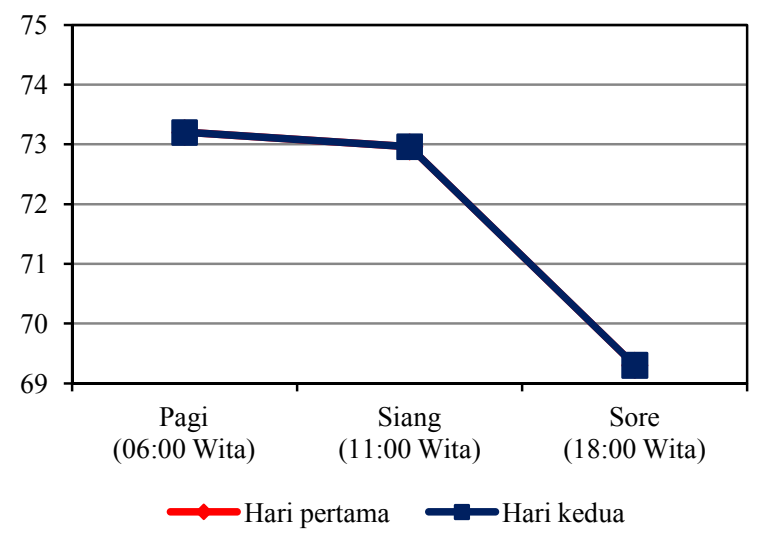

Gambar 2. Grafik kadar air pada ikan Cakalang (Katsuwonus pelamis L).

\section{Uji Organoleptik Ikan Selar dan Ikan Cakalang}

Dari hasil uji Organoleptik pada 15 panelis yang agak terlatih masing-masing mempunyai penilaian yang sama dengan organ tubuh pada ikan Selar dan cakalang sehingga penulis menyimpulkan dari hasil uji organoleptik pada kriteria mata, insang, daging dan perut, bau, tekstur dapat dilihat pada Gambar 3-7.

Hasil Uji organoleptik pada 15 panelis yang ditunjukkan melalui Gambar 3 pada hari pertama dan kedua pada kriteria mata ikan Selar dan Cakalang, mempunyai penilaian yang sama 
pada jam 06:00 WITA. Menunjukkan mata ikan Selar dan Cakalang masih dalam keadaan segar dan jam 11:00/siang terjadinya penurunan kesegaran ikan yang masih baik. Sehingga pada jam 18:00/sore terjadi penurunan kesegaran ikan yang sangat signifikan. Sehingga untuk membandingkan hasil penelitian penulis dengan standar nilai organoleptik ikan segar di atas 7, dapat di simpulkan bahwa pada jam 06:0011:00 WITA ikan masih memenuhi SNI. Sedangkan pada jam 18:00 tidak memenuhi SNI. Walaupun demikian dari kriteria mata ikan selar dan cakalang masih bisa dikonsumsi.

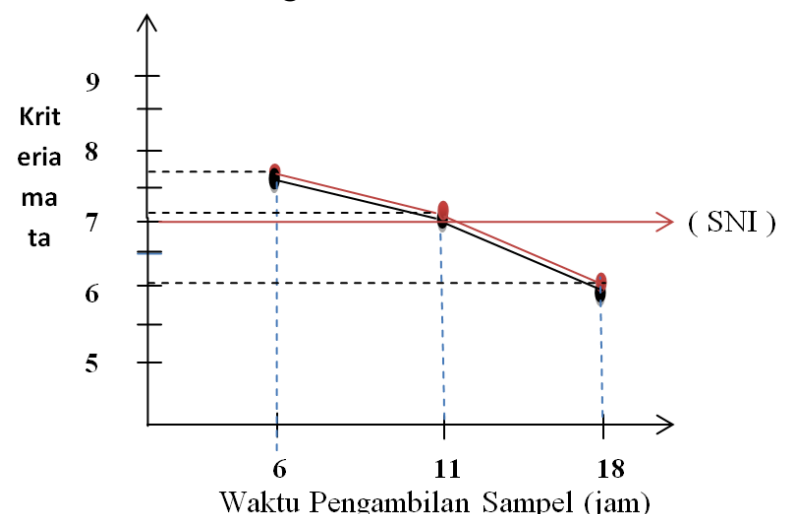

Gambar 3. Grafik organoleptik pada kriteria mata ikan Selar (Selaroides leptolepis) dan ikan Cakalang (Katsuwonus pelamis L).

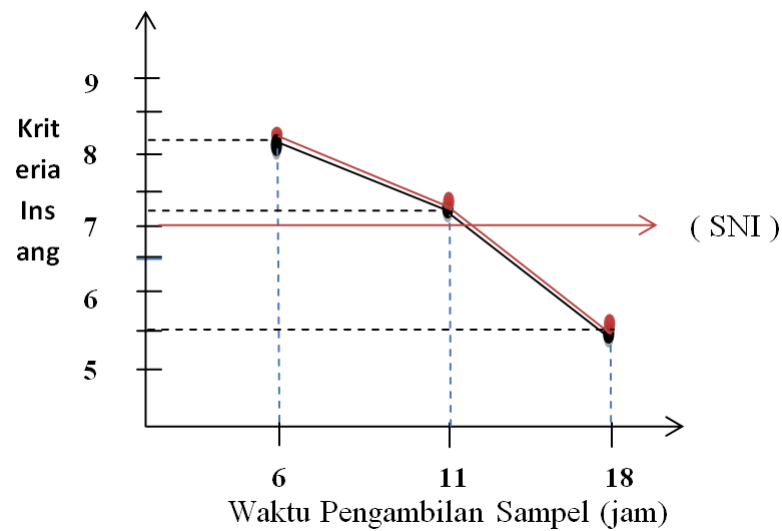

Gambar 4. Grafik organoleptik pada kriteria insang ikan Selar (Selaroides leptolepis) dan ikan Cakalang (Katsuwonus pelamis $\mathrm{L}$ ).

Hasil Uji organoleptik pada 15 panelis yang ditunjukan melalui Gambar 4 pada hari pertama dan kedua pada kriteria insang ikan Selar dan Cakalang, mempunyai penilaian yang sama pada jam 06:00 WITA. Menunjukkan mata ikan Selar dan Cakalang masih dalam keadaan segar dan jam 11:00/siang terjadinya penurunan kesegaran ikan yang masih baik. Sehingga pada jam 18:00/sore terjadi penurunan kesegaran ikan yang sangat signifikan. Sehingga untuk membandingkan hasil penelitian penulis dengan standar nilai organoleptik ikan segar di atas 7, dapat di simpulkan bahwa pada jam 06:00-11:00 WITA ikan masih memenuhi SNI. Sedangkan pada jam 18:00 tidak memenuhi SNI. Walaupun demikian dari kriteria mata ikan selar dan cakalang masih bisa dikonsumsi.

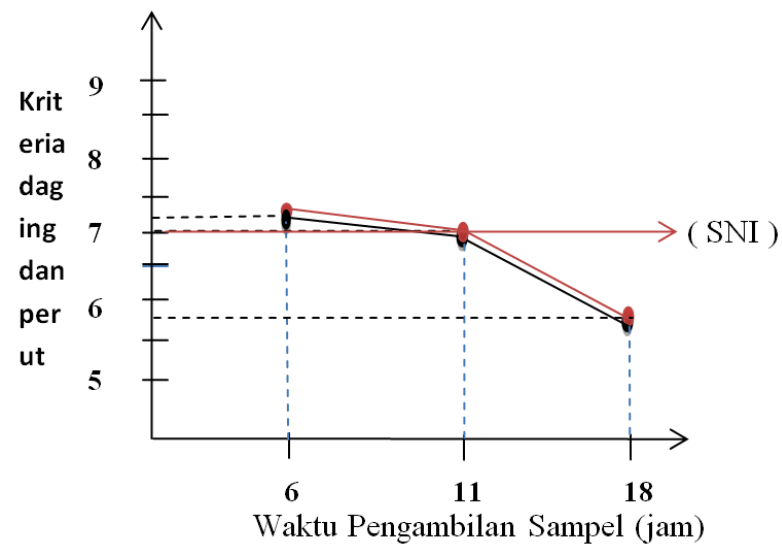

Gambar 5. Grafik organoleptik pada kriteria daging dan perut ikan Selar (Selaroides leptolepis) dan Cakalang (Katsuwonus pelamis $\mathbf{L}$ ).

Hasil Uji organoleptik pada 15 panelis yang ditunjukan melalui Gambar 5 pada hari pertama dan kedua pada kriteria daging dan perut ikan Selar dan Cakalang, mempunyai penilaian yang sama pada jam 06:00 WITA. Menunjukkan mata ikan Selar dan Cakalang masih dalam keadaan segar dan jam 11:00/siang terjadinya penurunan kesegaran ikan yang masih baik. Sehingga pada jam 18:00/sore terjadinya penurunan kesegaran ikan yang sangat signifikan. Sehingga untuk membandingkan hasil penelitian penulis dengan standar nilai organoleptik ikan segar di atas 7, dapat disimpulkan bahwa pada jam 06:00-11:00 WITA ikan masih memenuhi SNI. Sedangkan pada jam 18:00 tidak memenuhi SNI. Walaupun demikian dari kriteria daging dan perut ikan selar dan cakalang masih bisa dikonsumsi.

Hasil Uji organoleptik pada 15 panelis yang ditunjukkan melalui Gambar 6 pada hari pertama dan kedua pada kriteria bau ikan Selar dan Cakalang, mempunyai penilaian yang sama pada jam 06:00 WITA. Menunjukkan mata ikan selar dan cakalang masih dalam keadaan segar, dan jam 11:00/siang terjadinya penurunan kesegaran ikan yang masih baik. Sehingga pada jam 18:00/sore terjadi penurunan kesegaran ikan yang sangat signifikan. Sehingga untuk 
membandingkan hasil penelitian penulis dengan standar nilai organoleptik ikan segar di atas 7 , dapat disimpulkan bahwa pada jam 06:00-11:00 WITA ikan masih memenuhi SNI. Sedangkan pada jam 18:00 tidak memenuhi SNI. Walaupun demikian dari kriteria bau ikan selar dan cakalang masih bisa dikonsumsi.

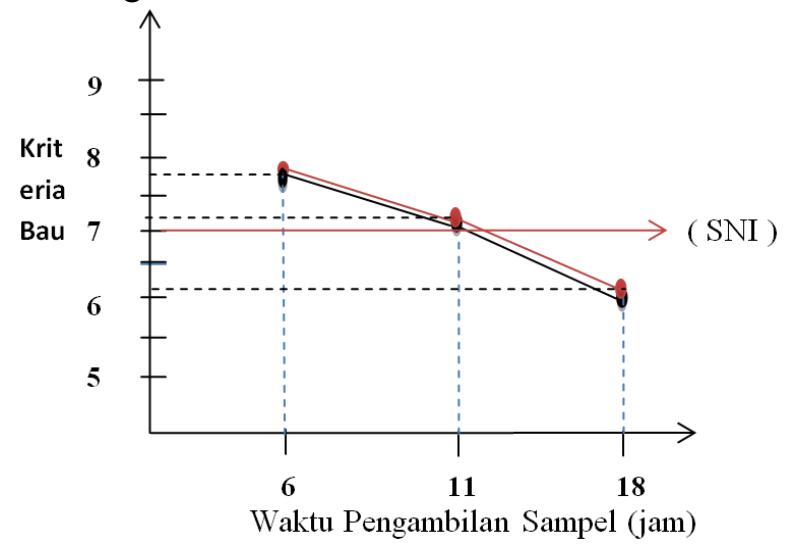

Gambar 6. Grafik organoleptik pada kriteria bau ikan Selar (Selaroides leptolepis ) dan ikan Cakalang (Katsuwonus pelamis $\mathbf{L}$ ).

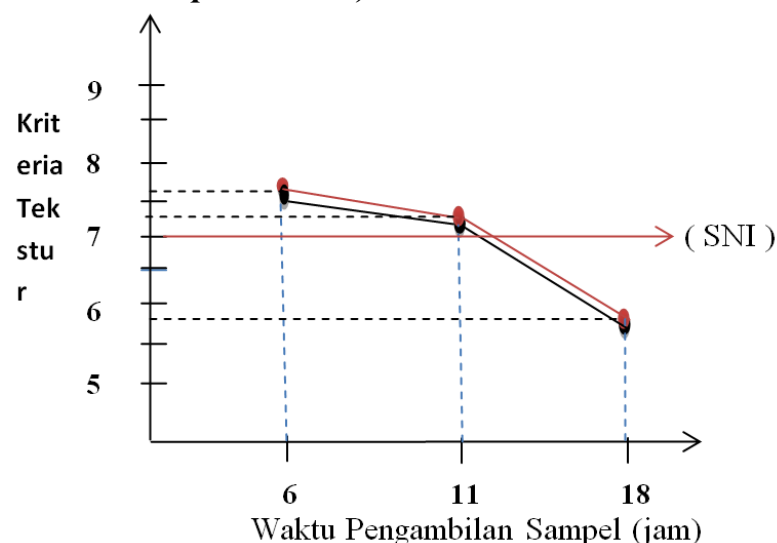

Gambar 7. Grafik organoleptik pada kriteria tekstur ikan Selar (Selaroides leptolepis) dan ikan Cakalang (Katsuwonus pelamis $\mathrm{L}$ ).

Hasil Uji organoleptik pada 15 panelis yang ditunjukkan melalui Gambar 7 pada hari pertama dan kedua pada kriteria tekstur ikan Selar dan Cakalang, mempunyai penilaian yang sama pada jam 06:00 WITA. Menunjukkan mata ikan Selar dan Cakalang masih dalam keadaan segar dan jam 11:00 terjadinya penurunan kesegaran segar, dan pada jam 18:00/sore terjadi penurunan kesegaran ikan yang sangat signifikan. Sehingga untuk membandingkan hasil penelitian penulis dengan standar nilai organoleptik ikan segar di atas 7, dapat disimpulkan bahwa pada jam 06:00-11:00 WITA ikan masih memenuhi SNI. Sedangkan pada jam 18:00 tidak memenuhi SNI. Walaupun demikian dari kriteria tekstur ikan selar dan cakalang masih bisa dikonsumsi.

\section{KESIMPULAN}

Hasil analisa kadar air pada dua jenis ikan pelagis, masih baik dalam kisaran SNI yaitu $70-80 \%$. Hasil uji organoleptiknya (mata, insang, daging dan perut, bau, tekstur) masih baik sampai pada pukul 11:00/siang, dan pada pukul 18:00 WITA tidak masuk dalam kisaran standar (SNI) tapi ikan tersebut masih bisa dikonsumsi.

\section{DAFTAR PUSTAKA}

Afrianto, E dan E. Liviawaty, 1989. Pengawetan Dan Pengolahan Ikan. kanisius. Yogyakarta.

IIyas, S. 1983. Teknologi Refrigerasi Hasil Perikanan. Jilid I. Teknik Pendinginan Ikan. Jakarta.

Mantjoro, E. 1981. Metodologi Penelitian. Fakultas Perikanan Universitas Sam Ratulangi. Manado.

Moeljanto. 1982. Penanganan Ikan Segar. Penebar Swadya. Jakarta.

Nontji A. 1987. Laut Nusantara. Penerbit Djembatan. Jakarta.

Rompon, S. 2002, Tingkat Ketengikan Ikan Kakatua (Callyodon sp) Asin di Beberapa Pasar di Manado. Fakultas Perikanan dan Ilmu Kelautan. UNSRAT Manado.

Standarisasi Nasional Indonesia (SNI 01-2346-1991) Uji Organoleptik Ikan Segar. Jakarta.

Sudarmadji, S.B.; Haryono; dan Suhardi,. 1997. Analisa Bahan Makanan dan Pertanian. Liberty. Yogyakarta. 